\title{
Utilization of Solid Waste from Sago Flour Industry (Sago Pith Waste) as Biodegradable Plastic
}

\section{Ade Rizki Fauziah1, Mahatma Lanuru², Muh Syahrul'3 , Shinta Werorilangi', Budimawan5, Baharuddin', and Eymal Bahsar Demmallino ${ }^{7}$}

\footnotetext{
${ }^{1}$ Hasanuddin University, Student of Department of Environmental Management, Graduate Studies Program, Makassar, Indonesia.

${ }^{2}$ Hasanuddin University, Department of Marine Sciences, Faculty of Marine and Fisheries, Makassar, Indonesia.

${ }^{3}$ Hasanuddin University, Department of Chemistry, Faculty of Mathematic and Natural Science, Makassar, Indonesia.

${ }^{4}$ Hasanuddin University, Department of Marine Sciences, Faculty of Marine and Fisheries, Makassar, Indonesia.

${ }^{5}$ Hasanuddin University, Department of Marine Sciences, Faculty of Marine and Fisheries, Makassar, Indonesia.

${ }^{6}$ Hasanuddin University, Faculty of Forestry, Makassar, Indonesia.

${ }^{7}$ Hasanuddin University, Head of Department of Environmental Management, Graduate Studies Program, Makassar, Indonesia.
}

Correspondence Author: Ade Rizki Fauziah. Hasanuddin University, Student of Department of Management Environmental, Graduate Studies Program, 90245, Makassar, Indonesia

E-mail: fauziahade@gmail.com

Received date: 12 December 2019, Accepted date: 28 January 2020, Online date: 31 January 2020

Copyright: (C) 2020 Ade Rizki Fauziah et al., This is an open-access article distributed under the terms of the Creative Commons Attribution License, which permits unrestricted use, distribution, and reproduction in any medium, provided the original author and source are credited.

\begin{abstract}
Plastic has been widely recognized in people's daily lives. Plastic is a synthetic polymer made from crude oil with various additives. Plastic waste is one of global problem because it takes thousands of years to decompose. There has been solution proposed, one of which is the use of biodegradable plastic. In this study we have used starch from sago waste, especially sago pith waste. The aims of this study (1) to synthesize biodegradable plastic based on sago waste starch; (2) to get the characteristics of biodegradable plastic. Biodegradable plastic was synthesized using starch from sago pith waste with various concentration ( $5 \mathrm{gr}, 10 \mathrm{gr}, 15 \mathrm{gr}$, and $20 \mathrm{gr}$ ) mixed with glycerin and aquades. Biodegradable plastic dough was printed and heated in an oven at $120^{\circ} \mathrm{C}$ for 12 hours Then, the solutions were heated in a magnetic stirrer at temperature $150^{\circ} \mathrm{C}$ and $600 \mathrm{rpm}$ for 25 minutes. The aspects studied were moisture absorption, tensile strength, elongation, and biodegradability. The results show that plastic based sago waste has the best water absorption was at a composition of 20 gr of starch with value $6.075 \%$. Also, the best tensile strength and elongation were in the composition of $10 \mathrm{gr}$ of starch with values of $2.694 \mathrm{~N} / \mathrm{mm}^{2}$ and $18.015 \%$, respectively. Soil burial test method shows biodegradable plastic can be degraded with $>80 \%$ presentation after 20 days. The addition of a large concentration of starch would accelerate degradation process, but decrease moisture absorption. It's indicated that sago pith waste starch shows the high potential for making biodegradable plastic.
\end{abstract}

Keywords: Sago pith waste, Starch, Glycerin, Biodegradable Plastic.

\section{INTRODUCTION}

Plastic has been widely recognized in people's daily lives. Plastic is one of the essential materials that are used in food packaging due to the advantages that are reflected in their physical properties [1]. The majority of plastic available on the market comes from petroleum resources [2]. Plastic is a synthetic polymer made from crude oil with various additives [3]. Synthetic polymers, including materials that are quite difficult to be degraded by nature or known as "non-biodegradable" because it is persistent that lasts for hundreds of years without being degraded, causing pollution and environmental damage [4, 5].

Along with technological developments, one solution to overcome the problem of plastic waste is by creating an environmentally friendly alternative to conventional plastics, such as biodegradable plastic. Biodegradable plastics are plastics developed from natural resources such as biomass materials from agriculture, which were environmentally friendly [6]. The term "biodegradable" refers to materials that can destroy or break down naturally into biogas and biomass as a result of exposure to the microbial environment and humidity [7].

Previous studies reported biodegradable plastics based natural resources such as; rice protein [8], sago starch [9], and starch/chitosan with additional pineapple leaf [6]. The focus of their research was on mechanical properties, biodegradation, and 
other properties. Among these biopolymers, starch is one of the promising materials because of its available in huge quantities, low cost, renewable resources and inherent biodegradability [10, 12].

In this study, we have used starch from sago waste, especially sago pith waste. Besides, having a lot of starch, sago pith waste can also be used as animal feed because the superiority of complete feed is balancing nutrition, cheap material and also the raw materials derived from agricultural and agro-industrial waste treatment [12]. But, the focus of this research about how to make biodegradable plastic from sago pith waste starch.

According to [13], the composition on sago pith waste on a dry basis can be seen in figure 1. Based on this composition, sago pith waste has the potential to be developed as a raw material for making biodegradable plastics which are expected to be able to obtain higher mechanical properties and faster degradation times. Besides, its utilization can be a solution to environmental problems in reducing sago waste that has not been utilized optimally.

Table 1: Component sago pith waste on a dry basis

\begin{tabular}{|c|c|}
\hline Component & Amount (\%) \\
\hline Starch & 58 \\
\hline Cellulose & 23 \\
\hline Hemicellulose & 9,2 \\
\hline Lignin & 4 \\
\hline
\end{tabular}

\section{METHODOLOGY}

\section{Materials}

Glycerin (C3H8O3) (molecular weight 92.09, boiling points $290^{\circ} \mathrm{C}$ ) (Merck), sago pith waste starch from CV. Podomoro Makassar, and aquades (Merck).

\section{Preparation of sago pith waste starch}

Sago pith waste is obtained from Sago Flour Industry CV. Podomoro Makassar. Sago pith waste that has been obtained in weighing as much as $1 \mathrm{~kg}$. Then, sago pith waste was soaked with clean water as much as 2 liters so that the starch solution was obtained. Next, starch solutions were dried in sundry for 12 hours and were sieved using 100 mesh [14].

\section{Synthesis of Bioplastic}

Sago waste starch with various concentrations (5 gr, $10 \mathrm{gr}, 15 \mathrm{gr}$, and $20 \mathrm{gr}$ ) was added to $3 \mathrm{ml}$ glycerin and $100 \mathrm{ml}$ aquades [16]. Then, the solutions were stirred using a magnetic stirrer for 5 minutes at $600 \mathrm{rpm}$. After that, the solutions were heated in a magnetic stirrer at temperature $150^{\circ} \mathrm{C}$ and $600 \mathrm{rpm}$ for 25 minutes. Each stirred solution was poured into mould, then dried in the oven with temperature $120^{\circ} \mathrm{C}$ for 12 hours. For a clear illustration of the synthesis process in this study is shown in Figure 1.

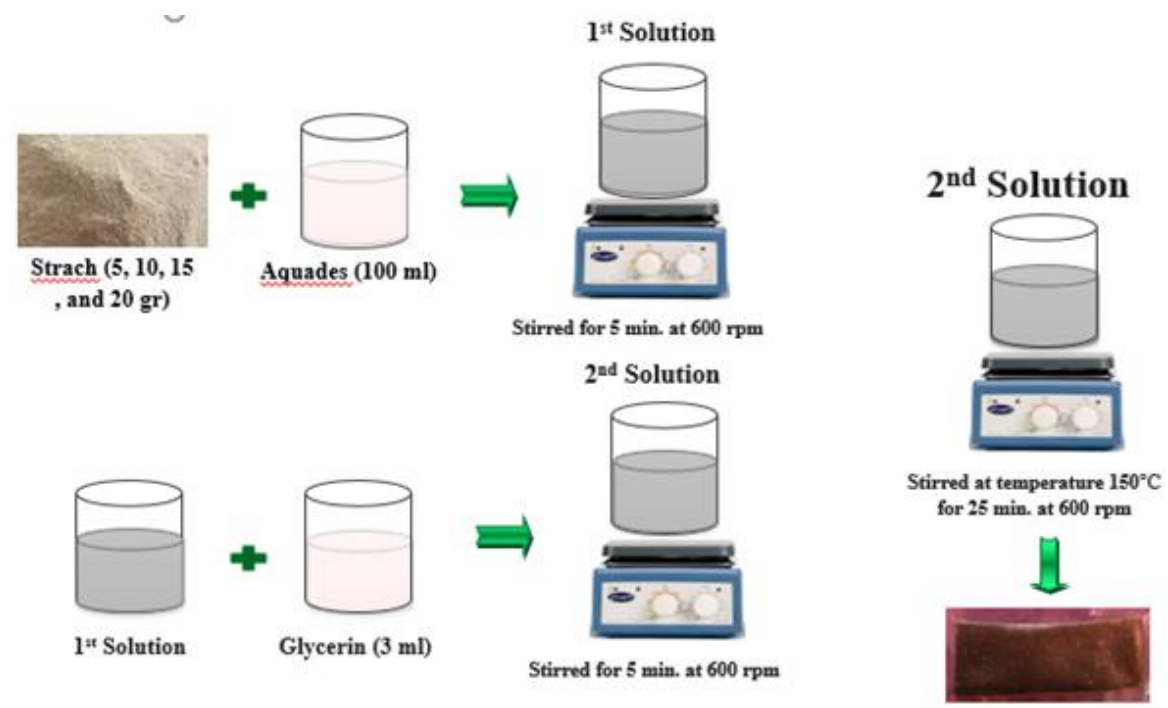

Fig. 1: Synthesis processes of the bioplastics from sago pith waste starch.

\section{Characterization \\ Water Absorption}

Biodegradable plastics, which had been previously dried for 12 hours in an oven at $120^{\circ} \mathrm{C}$, cooled in a desiccator, and weighed, were cut into small size. The moisture absorption data of bioplastics was obtained by soaking them in water for 3 minutes [16]. After that, the bioplastics were dried with a cloth and immediately weighed. The water absorption capacity of bioplastics can be calculated as follows [17]. 
Water Absorption $(\%)=\frac{(\text { Post-Bake weight })-(\text { initial weight })}{\text { initial weight }} \times 100$

\section{Tensile Strength Test}

The biodegradable plastic sample was cut to $5 \mathrm{~cm}$ x $3 \mathrm{~cm}$. The tensile strength test of the samples was determined using method ASTM D638-02a-2002 [18].

\section{Elongation Test}

The biodegradable plastic sample was cut to $5 \mathrm{~cm} \mathrm{x} 3 \mathrm{~cm}$. Elongation test of the samples was determined using method ASTM D638-02a-2002 [18].

\section{Biodegradation test}

Biodegradability material was detected through a soil burial test method [17]. In the beginning, the samples were weight was recorded as initial data. This test was carried out by stockpiling the sample under the ground for 5 days, 10 days, 15 days and 20 days. Any changes in mechanical properties due to degradation processes were observed and when the bioplastics were completely degraded, biodegradability was measured [6].

Microbial Resistance $(\%)=\frac{\text { (initial mass })-(\text { final weight })}{\text { initial weight }} \times 100$

\section{RESULT AND DISCUSSION}

\section{Water Absorption}

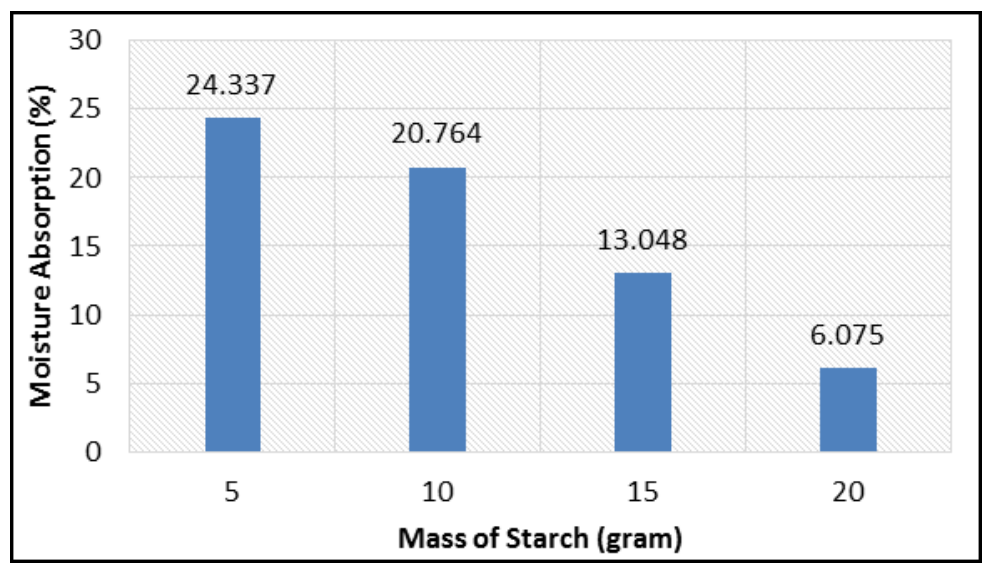

Fig. 2: Result of Water Absorption Testing

Figure 2 shows the amount of moisture absorbed by the bioplastic sample with the various components of starch.

Based on figure 2, the water absorption test shows the maximum value at $6.075 \%$ on the sample composition 20 gr starch. The more the starch is, the lower the swelling water ratio will be. The moisture absorption decreased with increasing starch composition. Glycerin and starch called hydrophilic properties, these properties increase water absorption [14]. The National Standardization Agency (BSN) issued a national standardization of biodegradable bioplastics (in 2016 with the reference code of SNI 7188.7: 2016. In SNI 7188.7: 2016 explained the standard water absorption of bioplastic shows the value at 21.4\% and temperature $25^{\circ} \mathrm{C}$. So that, biodegradable plastic in this study have fulfilled SNI [15]. The previous research reported from [16], shows that the water absorption based on sago waste starch using the composition of $0 \%$ gelatin obtained water absorption $44.3 \%$. This result was not optimum when compared with research based on sago pith waste starch produced by studies that have met conventional plastic standards (SNI).

\section{Tensile Strength Test}




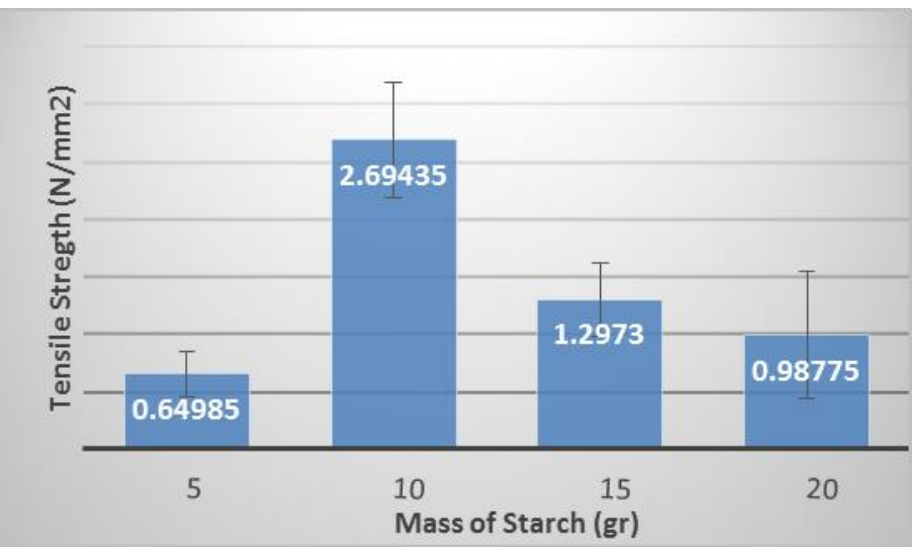

Fig. 3: Result of Tensile Strength Test

Figure 3 shows the results of the tensile strength of starch. The maximum tensile strength of $2,3363 \mathrm{~N} / \mathrm{mm}^{2}$ was obtained from composition $10 \mathrm{gr}$ of carbohydrate. This result confirms that the addition of starch can reduce the value of biodegradable plastic tensile strength because there was space that occurred in bonds between polysaccharides broken by glycerin and causes relationships between molecules in biodegradable plastic to weaken and intermolecular mobility increases [18].

\section{Elongation Test}

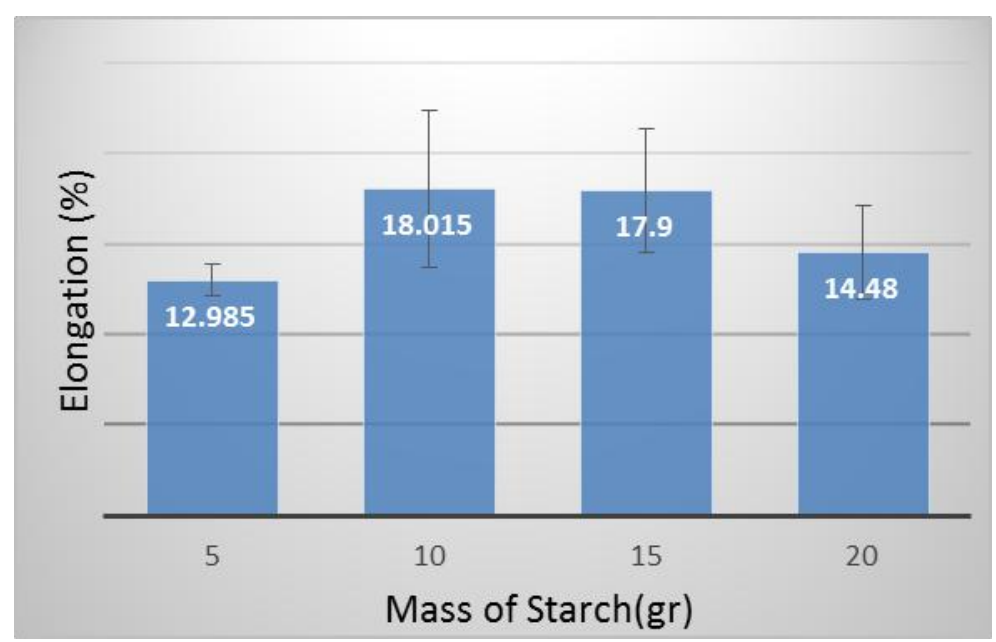

Fig. 4: Result of the Elongation Test

Figure 4 shows the results of the elongation of biodegradable plastic. The maximum elongation of 21,0 \% was obtained from composition $10 \mathrm{gr}$ of starch. The more starch is, the higher the hardness of biodegradable plastic. So, the results of the elongation test decreased and making biodegradable plastic is rigid and not elastic [18].

\section{Biodegradation Test}

The results of the biodegradation test of biodegradable plastic from sago pith waste starch with various concentrations $(5,10,15$, and $20 \mathrm{gr}$ ) for 5, 10, 15, and 20 days can be seen in figure 5. Biodegradable plastic with composition 20 gr of starch showed $80,543 \%$ degradation percentage compared to other compositions for 20 days. The difference is cleary for the low amount of starch is a low degradation too. And when the starch high, the degradation also increased. This shows that starch is playing an important role in degradation performance. The heavy loss of bioplastic samples during burial in soil shows the amount of degradation in the natural environment by the action of microorganisms. In cooperation with water and microorganisms, the structure of fibers and adhesive macromolecules break down or decay in different degrees [19]. 


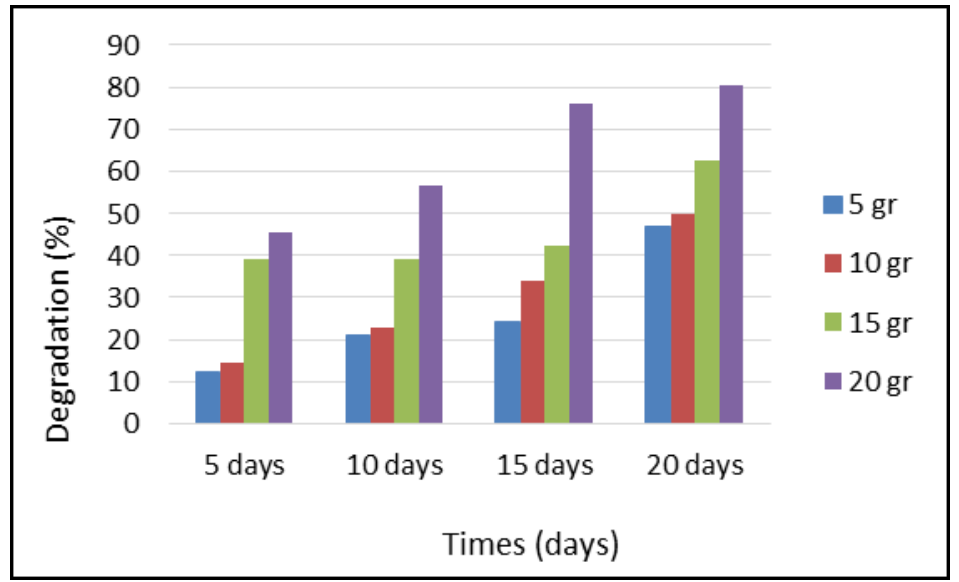

Fig. 5: Biodegradation test for biodegradable plastic with various compositions (5, 10, 15, and 20 gr).

\section{CONCLUSION}

Research on biodegradable plastic with sago pith waste starch as a base with variations concentration been synthesized. Biodegradable plastic from sago pith waste starch with the various components of starch has been studied by using tensile strength, elongation, water absorption and biodegradation test. Based on water absorption in bioplastics is influenced by the addition of glycerine. The maximum absorption is obtained in the composition of 20 grams of starch. The tensile strength and elongation test obtained maximum values at composition 10 grams of starch. Biodegradation analysis shows a higher percentage of degradation $>80 \%$ for 20 days. The results confirm that starch from sago pith waste has the potential to developed as a raw material for making bioplastics.

\section{Acknowledgments}

Professor Dahlang Tahir and Ms. Inayatul Mutmainnah for their assistance in synthesizing bioplastic. Also, the authors would like to acknowledge Hasanuddin University for laboratory facilities, especially the material laboratory department of physics during the completion of the research.

\section{REFERENCES}

[1] Tajeddin, B., Rahman, R. A., \& Abdulah, L. C. Mechanical and Morphological Properties of Kenaf Cellulose/LDPE Biocomposites. American-Eurasian J. Agric. \& Environ. 2009, 5 (6), 778-785.

[2] Ramakrishnan, N., Sharma, S., Gupta, A., \& Alashwal, B. Y. Keratin Based Bioplastic Film from Chicken Feathers and Its Characterizatio. Int J Biological Macromolecules. 2018, 111, 352-358. DOI: 10.1016/j.ijbiomac.2018.01.037.

[3] Goodshop, V. Plastic Recycling. (Conventry: University of Warwik). 2007.

[4] Bilo, F., Pandini, S., Sartore, L., Depero, L. E., Gargiulo, G., Bonassi, A., Fererici, S., \& Bontempi, E. A Sustainable Bioplastic Obtained from Rice Straw. J Clean Production. 2018, 200, 357-368.

[5] Thompson, R. C., Moore, C. J., Voom Saal, Frederick, S., \& Swan, S. H. The Environment and Human Health: Current Consensus and Future Trends. Philosophyal Transaction Royal Society J. 2009, 01, 1-14. https://doi.org/10.1098/rstb.2009.0053.

[6] Mutmainna, I., Tahir, D., Gareso, P. L., Ilyas, S., \& Saludung, A. Improving Degradation Ability of Composite Starch/Chitosan by Additional Pineapple Leaf Microfibers for Food Packaging Applcations. IOP Conf. Series: Material Science and Engineering. 2019, 593012024.

[7] Arikan, E. B., \& Ozoy, H. D. A Review: Investigation of Bioplastics. J Civil Engineering and Architecture. 2015, 9, 188192. DOI: $10.17265 / 1934-7359 / 2015.02 .007$.

[8] Yang, Y., Zhang, K., Song, Y., \& Zheng, Q. Preparation and Properties of Wheat Gluten / Rice Protein Composite Plasticized with Glycerol. J Chinese Polymer Science. 2011, 29 (1), 87-92. DOI: 10.1007/s10118-010-9185-8.

[9] Zawawi, Z. A. M., Akom, N. F., Dose, D., Syauwye, A., Ahmad, R. A., \& Yusoff, E. Biodegradable Plastic from Sago Starch. J Mechanical Engineering Department Politeknik Kuching Serawak. 2017, 1(1), 46-54.

[10]Zuraida, A., Yusliza, Y., Anuar, H., \& R. Muhaimin, M. K. The Effect of Water and Citric Acid on Sago Starch Bio-Plastic. International Food Research J.2012, 19, 715-719.

[11] Dewi, R., Agusnar, H., Wirjosentono, B., Halimah, \& Riza, M. Synthesis of Modified Thermoplastic Starch (TPS) Using InSitu Technique. Advances in Environmental Biology. 2014, 8 (18), 26-33.

[12] Rasyid, T. G., Hasan, S., Rasjid, S., \& Sirajuddin, S. N. Development Model of Goat Farming Business Base on Productive Economy in Majene Regency, West Sulawesi, Indonesia. J American-Eurasian: Sustainable Agriculture. 2016,10 (3), 1-5. DOI: $10.22587 / \mathrm{aeb} .2018 .12 .2 .1$. 
[13] Santoso, B. Recovery of Starch from Sago Pith Waste and Waste Water Treatment. Book of Sago Palm (Multiple Contributions to Food Security and Sustainable (Livehoods)). 2018, chapter 19 pp 261-269.

[14] Rifaldi, A., Irdoni, H. S., \& Bahruddin. Sifat dan Morfologi Bioplastik Berbasis Pati Sagu dengan Penambahan Filler Clay dan Plasticizer Gliserol. Jom FTeknik. 2014, 4(1), 1-7.

[15] Darni, Y., \& Utami, H. Studi Pembuatan dan Karakteristik Sifat Mekanik dan Hidrofobisitas Bioplastik dari Pati Sorgum. Jurnal Rekayasa Kimia dan Lingkungan. 2010, 7 (4), 88-93.

[16] Illing, I., \& Satriawan, M. B. Uji Ketahanan Air Bioplastik dari Limbah Ampas Sagu dengan Penambahan Variasi Konsentrasi Gelatin. Prosiding Seminar Nasional. 2017, 3(1), 182-189.

[17] Sofia, A., Prasetyo, A. T., \& Kusumastuti, E. Komparasi Bioplastik Kulit Labu Kuning-Kitosan dengan Plasticizer dari Berbagai Sumber Gliserol. J Indonesan Chemical Science. 2017, 6, 110-116.

[18] Jangong, O. S., Gareso, P. L., Mutmainna, I., \& Tahir, D. Fabrication and Characterization Starch/Chitosan Reinforced Polypropylene as Biodegradable. J Physics: Conference Series. 2019, 1341 082022. DOI: 10.1088/17426596/1341/8/082022.

[19] Rahmawati, H., Mutmainna, I., Ilyas, S., Fahri, A. N., Wahyuni, A. S. H., Afrianti, E., Setiawan, I., \& Tahir, D. Effect of Carbon on Structural and Bonding Characteristic of Bioplastic Based on Cassava Starch. ICePTi. 2019.

[20] Yuniarti, L. I., Hutomo, G. S., \& Rahim, A. Sintesis dan karakterisasi Bioplastik Berbasis Pati Sagu (Metroxylon sp.). e-J Agrotekbis. 2014, 2(1), 38-46. 